\title{
Respiratory disease in cork workers ('suberosis')
}

\author{
J. CORTEZ PIMENTEL and RAMIRO AVILA \\ Department of Pathology of Sanatorio D. Carlos I and Department of Chest Diseases and \\ Institute of Pathology, Faculty of Medicine, University of Lisbon, Portugal
}

\begin{abstract}
Pimentel, J. Cortez, and Avila, Ramiro (1973). Thorax, 28, 409-423. Respiratory disease in cork workers ('suberosis'). A clinical, immunological, and histological study of 63 workers in the cork industry with bronchopulmonary manifestations is described. From this study, it was possible to recognize three types of reaction to the inhalation of cork dust: asthma-like syndromes, extrinsic allergic alveolitis, and chronic bronchitis with bronchiectasis. The place of histological (lung biopsy and scalene node biopsy) and immunological methods in the diagnosis of these different forms of the disease is evaluated. The high incidence of precipitins to Penicillium frequentans is stressed because the antigens produced by this fungus seem to be more pathogenic than those produced by the mouldy cork itself. The histological studies have demonstrated extrapulmonary foci of disease and have also revealed for the first time, abnormalities in the lungs of symptomless subjects. Pathological changes present in the lungs of patients with the chronic form of extrinsic allergic alveolitis, long after removal from exposure to cork dust, are also described. The experimental material of Horta and Cancella (1956) is reviewed in the light of present knowledge, and the similarity between the lesions produced in animals and those found in cork workers is noted. Finally, especial importance is attached to the finding of cork dust within the lesions, the technique for its identification and staining being described.
\end{abstract}

Workers in factories where cork is processed and transformed into commercial products may acquire incapacitating disease of the respiratory tract.

Cancella (1955) named this disease 'suberosis' and considered it a pneumoconiosis due to cork dust. Later, the same author (Horta and Cancella, 1956) reported the pathological changes found in the lungs of five cork workers but was unable to demonstrate that the dark pigment found within the lesions was actually cork dust. Avila and Villar (1968) distinguished patients with asthma-like symptoms from others with manifestations of interstitial or alveolar involvement. Many of these patients were studied using antigens produced from mouldy cork and from 'clean' cork. Pimentel (1969) reported the occurrence of epithelioid granulomata, similar to those found in farmer's lung, in suberosis, and in 1971 described for the first time a technique for staining the cork dust within the lesions using cochineal red.

Finally, Avila and Araújo (1971) noted an association between atopic manifestations and symptoms of alveolar changes, based on the 1This work was supported by the Instituto de Alta Cultura, Portugal (Research Project LMe5) responses to skin and inhalational provocation tests.

In the present study we consider the clinical, histological, and immunological aspects of the disease in 63 patients. The morphological findings in the lungs of symptomless cork workers and in the lungs of workers who have been removed from exposure to cork dust for long periods of time are described and the diagnostic value of histological findings and immunological tests will be discussed.

\section{MATERIAL AND METHODS}

(1) Clinical, radiological, laboratory, functional, and histological studies were made on 63 cork workers. Immunological studies were performed on 34 of these patients.

The clinical manifestations were grouped as follows: (a) 13 had an asthma-like syndrome when exposed to cork dust; (b) 20 had symptoms of extrinsic allergic alveolitis in an acute phase and 16 in a chronic phase; (c) 16 had signs of chronic bronchitis with bronchiectasis and had been treated by pulmonary resection.

Special attention was given to the time lapse between the beginning of exposure to cork dust and the appearance of symptoms, their abrupt or in- 
sidious onset and the chronology of the complaints. In the chronic forms the different aspects of the course and duration of exposure were considered. The presence or absence of signs of bronchial irritation or of extrinsic allergic alveolitis preceding these chronic stages were also noted. Signs of atopy and their relation to exposure were investigated.

(2) Pathological examination of the lungs of six asymptomatic cork workers, who died of accidental causes, was carried out.

(3) Clinical and pathological studies were made on two patients with symptoms of the chronic stage of extrinsic allergic alveolitis, who had been removed from exposure to cork dust due to invalidism after 35 and 40 years of exposure and died respectively seven and two years later from diseases not related to their work.

(4) Histological studies were made on 16 scalene node biopsies from patients with pulmonary lesions due to cork dust, later confirmed by lung biopsy, surgical specimens, or necropsy.

(5) Histological studies were made on five biopsies of the nasal mucosa in cork workers complaining of sneezing and rhinorrhoea.

(6) Studies were made of the lung changes in 23 guinea-pigs and 7 rabbits exposed to cork dust in the various departments of the Mundet Cork Factory in Montijo. The time of exposure of the guinea-pigs varied from 56 to 1,278 days, and of the rabbits from 276 to 1,100 days. For this study we used the material included in paraffin blocks from the original experiments of Horta and Cancella (1956) and on file in the Pathology Department.

MYCOLOGICAL STUDIES Fungi were cultivated from various samples of cork in order to identify them. They were also counted with the Andersen sampler, and antigens were prepared from them for immunological studies. This part of the study was made possible by the kind help of Dr. John Lacey of Rothamsted Experimental Station, Harpenden, England, to whom we are greatly indebted.

IMMUNOLOGICAL STUDIES Antigens These were prepared from (1) cork dust 'without fungi', from the transformation of the finished dry cork into objects such as stoppers and discs; (2) cork with 'traces of fungi' which was beginning to get mouldy after the various operations to which it was submitted after removal from the cork oak-boiling, stacking while damp in hot warehouses, and choosing; (3) various species of fungi cultivated from the cork. The proteins of the cork were extracted with Coca's fluid. This was then filtered, dialysed, and freeze-dried according to the technique of Pepys, Longbottom and Jenkins (1964). In preparing the fungal antigens the technique of consecutive congelation and decongelation described by Hearn and Holford-Strevens (1968) was used, followed by extraction with Coca's fluid, filtration, dialysis, and freeze-drying. The freeze-dried material was then dissolved to the desired concentration in normal saline solution for the immuno- chemical studies and in Coca's fluid for skin and inhalational provocation tests.

Human sera The sera of the following subjects were used for the immunochemical studies: 34 bloof donors ; 67 patients with various pulmonary disease $\$$ from the outpatient clinic of the Department of Chest Diseases, who had never been exposed to cork? dust; 13 patients with bird fancier's disease; patients with farmer's lung; 19 patients with an aspergilloma; 20 unaffected cork workers; 15 corls workers with asthma; 16 patients with extrinsict allergic alveolitis; and one patient with chroni $\bar{\alpha}$ bronchitis and bronchiectasis.

Double diffusion in agar The techniques described by Pepys et al. (1964) were used. The cork antigen ${ }^{t}$ were used in concentrations of $40 \mathrm{mg} / \mathrm{ml}$ and funga? antigens of $50 \mathrm{mg} / \mathrm{ml}$.

Immunoelectrophoresis The original technique of Scheidegger (1955) with slight modifications alread
reported (Avila, 1965) were used.

Skin sensitivity tests An intradermal injection in $\overrightarrow{0}$ the forearm of $0.2 \mathrm{ml}$ of a solution of $5 \mathrm{mg} / \mathrm{ml}$ of Coca's fluid was made. The same amount of Coca' fluid was injected $7 \mathrm{~cm}$ from the test site as control. Readings were taken at 20 minutes and $3,4,5,6$, and 7 hours after the injection.

Inhalational provocation tests The patients were subळ mitted to an aerosol of $1 \mathrm{ml}$ of a solution of $5 \mathrm{mg} / \mathrm{m}$ of antigen in Coca's fluid after they had beer? examined. The axillary temperature was taken, and the following ventilatory parameters were measuredvital capacity (VC), forced expired volume in one. second $\left(\mathrm{FEV}_{1}\right)$, and $\% \mathrm{FEV}_{1} / \mathrm{VC}$. This routine was repeated 20 minutes and $3,4,5,6$, and 7 hours afte? the provocation. Whenever possible the CO transfe factor was determined before and 7 hours aftei provocation.

Histological Data These were derived from speciô mens obtained by bronchial, transbronchial, and per cutaneous needle biopsies. Other tissues studied were surgical biopsy specimens of the lung, scalene lymph nodes, and liver. Further data were obtained fromo necropsy specimens. The biopsy specimens were fixe in $10 \%$ neutral formalin. Lungs were fixed by intra $N$ bronchial perfusion of formalin. Paraffin sections of the specimens were cut and stained with haema toxylin and eosin, the periodic acid Schiff reaction and by special staining techniques for reticulin fibres? elastic fibres, collagen, fungi, acid-fast bacilli, and calcium salts. In some cases it was necessary tof exclude a diagnosis of tuberculosis, and in these the tubercle bacilli were searched for by direct smears, by culture on appropriate media, and by inoculation into guinea-pigs. In all cases the cochineal red stair for cork dust (Pimentel, 1971) was carried out a? follows: (1) A stock solution of a saturated solution of cochineal red in pure isopropanol-approximately $99 \%$ with the commercial product-was prepared (2) The stock solution was diluted by adding siof . 
parts to four parts of water. After 10 minutes the resultant mixture was filtered and used immediately for staining. (3) The sections were stained for 20-30 minutes, washed rapidly in isopropanol, and mounted in glycerin jelly.

\section{RESULTS}

ASTHMA-LIKE SYNDROMES (13 patients) These patients showed the usual clinical picture of asthma-an obstructive ventilatory syndrome. An eosinophilia was always present in the blood. Chest radiographs were normal in all patients except two who displayed fleeting pulmonary infiltrates. Skin sensitivity tests with mouldy cork antigen gave immediate wheal reactions, maximal at 10-15 minutes and disappearing within 1-2 hours. Inhalational provocation tests produced an immediate bronchial reaction with a marked fall in $\mathrm{VC}$ and in $\mathrm{FEV}_{1} / \mathrm{VC}$ to below $70 \%$.

The study of the bronchial biopsy specimens in these cases revealed oedema and often an inflammatory exudate in the mucosa. This consisted of a granulomatous reaction with lymphocytes and histiocytes and considerable numbers of eosinophils. In three cases there was a proliferation of fibroblasts with increased vascularity and a formation of reticulin fibres. In two cases there was a nodular proliferation of histiocytes together with a granulomatous appearance. Cork dust was seen within the histiocytes. In two of these patients transbronchial lung biopsy specimens showed that

T A B L E I

\begin{tabular}{|c|c|c|}
\hline & \multicolumn{2}{|c|}{ Acute Form } \\
\hline & $\begin{array}{l}\text { Acute Course } \\
(2 \text { patients })\end{array}$ & $\begin{array}{l}\text { Insidious Course } \\
\text { (18 patients) }\end{array}$ \\
\hline Symptoms & $\begin{array}{l}\text { Dyspnoea, dry cough, } \\
\text { weakness, malaise, } \\
\text { fever, muscular pains, } \\
\text { and weight loss }\end{array}$ & $\begin{array}{l}\text { Dyspnoea, cough with } \\
\text { mucoid sputum } \\
\text { which became } \\
\text { purulent, weakness, } \\
\text { malaise, and loss of } \\
\text { weight }\end{array}$ \\
\hline Physical signs & $\begin{array}{l}\text { Fine rales, mostly basal, } \\
\text { during episodes }\end{array}$ & $\begin{array}{l}\text { Disseminated rhonchi } \\
\text { associated with fine } \\
\text { rales, mostly basal, } \\
\text { during exacerbations }\end{array}$ \\
\hline Radiology & $\begin{array}{l}\text { Fine miliary mottling } \\
\text { with occasional dense } \\
\text { opacities. These } \\
\text { changes disappeared } \\
\text { within } 2 \text { to } 5 \text { weeks }\end{array}$ & $\begin{array}{l}\text { Normal in one patient } \\
\text { The others had fine } \\
\text { miliary mottling and } \\
\text { more or less marked } \\
\text { fibrosis }\end{array}$ \\
\hline Bronchoscopy & $\begin{array}{l}\text { Congested and } \\
\text { oedematous mucosa } \\
\text { with secretions coming } \\
\text { from lobar bronchi }\end{array}$ & $\begin{array}{l}\text { Normal in one patient. } \\
\text { The others were } \\
\text { identical with the } \\
\text { acute cases }\end{array}$ \\
\hline $\begin{array}{l}\text { Laboratory } \\
\text { findings }\end{array}$ & $\begin{array}{l}\text { Increase in gammaglo- } \\
\text { bulin in both patients. } \\
\text { Increase in } \alpha^{2} \text { globulin } \\
\text { in one patient }\end{array}$ & $\begin{array}{l}\text { Increase in gammaglo- } \\
\text { bulin in } 9 \text { of the } 12 \\
\text { patients studied. } \\
\text { Increase in } \alpha^{2} \text { globu- } \\
\text { lin in } 9 \text { of the } 12 \\
\text { patients studied }\end{array}$ \\
\hline
\end{tabular}

some of the alveolar septa were thickened by reticulin or collagen fibres, or by a cellular infiltration in which lymphocytes, histiocytes, and fibroblasts predominated. Small accumulations of cork dust were seen in granular pneumocytes within the alveoli or in histiocytes in the cellular infiltrations in the septal wall. In one case the lungs of a cork worker with an asthma-like syndrome were examined at necropsy. In this case the lungs showed a pronounced infiltration of the walls of bronchi of various diameters, and this cellular infiltration extended into surrounding connective tissue and into interlobular and alveolar septa. Even beyond these surrounding areas there was thickening of the alveolar septa by reticulin fibres, fibrous tissue, and a cellular infiltration. Two small granulomata composed of epithelioid cells and sarcoid-like in type were seen in an interlobular septum. When these were stained by the cochineal red technique they showed considerable deposits of cork dust, particularly in intra-alveolar granular pneumocytes and also in the cellular infiltration around the bronchus, in intra-alveolar septa, and in granulomata.

EXTRINSIC ALLERGIC ALVEOLITIS The acute stage of the disease presented clinically either in acute attacks or insidiously. Tables I and II summarize the principal clinical, radiographic, endoscopic, laboratory, and functional findings in these patients. The immunological behaviour of these workers was studied by challenging them with antigens prepared from mouldy cork and from the fungi isolated from it (Tables III and IV). These results are of particular interest in respect of Penicillium frequentans. In Tables V, VI, and VII, the results of the different immunological tests are summarized and the responses to mouldy cork and Penicillium frequentans antigens are compared. When using immunoelectrophoresis no positive results were obtained with the mouldy cork antigens yet with the Penicillium antigens the results were the same as in double diffusion (Fig. 1).

Lung biopsy specimens taken from cork workers during the stage of acute crisis showed variable degrees of thickening of the alveolar septa due to their infiltration by histiocytes, lymphoblasts, fibroblasts, and oedema fluid. Deposits of cork dust were seen in the intra-alveolar granular pneumocytes and in some of the histiocytes in the septal walls. In two cases there were granulomata reminiscent of tuberculosis or sarcoidosis which consisted of epithelioid cells with Langhan's or foreign body giant cells. Frequently there was a surrounding border of lymphocytes with associated cork dust (Fig. 2). There was thickening of the septa by the 
T A B LE I I

\begin{tabular}{|c|c|c|c|c|c|c|c|c|c|c|}
\hline \multirow{2}{*}{\multicolumn{2}{|c|}{ Extrinsic Allergic Alveolitis }} & \multicolumn{5}{|c|}{ Ventilation Studies } & \multicolumn{3}{|c|}{ Blood Gases } & \multirow{3}{*}{$\begin{array}{c}\text { Co Transfer } \\
\text { Factor } \\
\text { (Normal values } \\
\text {-above } 10 \mathrm{ml} \\
\mathrm{min} / \mathrm{mmHg} \text { ) }\end{array}$} \\
\hline & & \multicolumn{2}{|c|}{ VC } & \multicolumn{2}{|c|}{ FEV $^{1}$} & \multirow[b]{2}{*}{ VC/FEV } & \multirow[b]{2}{*}{$\underset{\left(\mathrm{mmHg}^{2}\right)}{\mathrm{PaO}_{2}}$} & \multirow[b]{2}{*}{$\underset{(\mathrm{mmHg})}{\mathrm{PaCO}_{2}}$} & \multirow[b]{2}{*}{ pH } & \\
\hline $\begin{array}{c}\text { Mode of } \\
\text { Presentation }\end{array}$ & Patient & $\mathrm{ml}$ & Predicted & ml & Predicted & & & & & \\
\hline Acute & $\begin{array}{l}\text { PC } 2 \\
\text { PC25 }\end{array}$ & $\begin{array}{l}3020 \\
3040\end{array}$ & $\begin{array}{l}71 \\
69\end{array}$ & $\begin{array}{l}2300 \\
2620\end{array}$ & $\begin{array}{l}77 \\
85\end{array}$ & $\begin{array}{l}76 \\
85\end{array}$ & $\begin{array}{l}69 \\
82\end{array}$ & $\begin{array}{l}27 \cdot 8 \\
37\end{array}$ & $\begin{array}{l}7 \cdot 40 \\
7 \cdot 43\end{array}$ & $\overrightarrow{22 \cdot 5}$ \\
\hline Insidious & $\begin{array}{l}\text { PC 6 } \\
\text { PC } 7 \\
\text { PC13 } \\
\text { PC20 } \\
\text { PC22 } \\
\text { PC24 } \\
\text { PC26 } \\
\text { PC31 } \\
\text { PC32 } \\
\text { PC34 } \\
\text { PC35 } \\
\text { PC39 } \\
\text { PC46 } \\
\text { PC47 }\end{array}$ & $\begin{array}{l}3200 \\
2480 \\
1560 \\
2200 \\
4200 \\
4300 \\
3020 \\
1280 \\
3940 \\
2340 \\
3080 \\
3474 \\
1416 \\
2574\end{array}$ & $\begin{array}{r}84 \\
61 \\
46 \\
63 \\
97 \\
98 \\
73 \\
36 \\
95 \\
75 \\
77 \\
102 \\
57 \\
70\end{array}$ & $\begin{array}{r}2340 \\
1200 \\
1200 \\
1100 \\
3900 \\
3960 \\
2060 \\
680 \\
2840 \\
2100 \\
2680 \\
1890 \\
1320 \\
1870\end{array}$ & $\begin{array}{r}88 \\
42 \\
51 \\
45 \\
128 \\
120 \\
71 \\
26 \\
108 \\
90 \\
90 \\
80 \\
76 \\
73\end{array}$ & $\begin{array}{l}73 \\
49 \\
76 \\
50 \\
92 \\
92 \\
68 \\
53 \\
72 \\
89 \\
87 \\
54 \\
93 \\
72\end{array}$ & $\begin{array}{r}70 \\
94 \\
88 \\
64 \\
94 \\
110 \\
90 \\
80 \\
90 \\
100 \\
72 \\
85 \\
80 \\
80\end{array}$ & $\begin{array}{l}36 \cdot 3 \\
40 \\
35 \\
38 \\
35 \\
40 \\
42 \\
39 \\
35 \\
26 \\
31 \\
29 \\
34 \\
32\end{array}$ & $\begin{array}{l}7 \cdot 36 \\
7 \cdot 40 \\
7 \cdot 46 \\
7 \cdot 40 \\
7 \cdot 47 \\
7 \cdot 45 \\
7 \cdot 42 \\
7 \cdot 49 \\
7 \cdot 51 \\
7 \cdot 48 \\
7 \cdot 43 \\
7 \cdot 46 \\
8 \cdot 42 \\
7 \cdot 41\end{array}$ & $\begin{array}{c}\overline{8 \cdot 9} \\
\overline{-} \\
14 \cdot 7 \\
19 \\
6 \cdot 1 \\
4 \cdot 5 \\
13 \\
6 \cdot 3 \\
16 \cdot 4 \\
8 \cdot 1 \\
\overline{5 \cdot 1}\end{array}$ \\
\hline Chronic & $\begin{array}{l}\text { PC48 } \\
\text { PC49 } \\
\text { PC50 } \\
\text { PC51 } \\
\text { PC52 } \\
\text { PC53 } \\
\text { PC54 } \\
\text { PC55 } \\
\text { PC56 } \\
\text { PC57 } \\
\text { PC58 } \\
\text { PC59 }\end{array}$ & $\begin{array}{r}790 \\
2350 \\
2500 \\
2500 \\
2700 \\
3100 \\
1300 \\
3400 \\
2440 \\
2750 \\
2700 \\
1450\end{array}$ & $\begin{array}{l}24 \\
64 \\
59 \\
71 \\
68 \\
79 \\
40 \\
77 \\
61 \\
61 \\
68 \\
52\end{array}$ & $\begin{array}{r}592 \\
1600 \\
1800 \\
1850 \\
1900 \\
2400 \\
1100 \\
2700 \\
1620 \\
1760 \\
1620 \\
943\end{array}$ & $\begin{array}{l}22 \\
63 \\
60 \\
75 \\
68 \\
88 \\
50 \\
87 \\
58 \\
56 \\
58 \\
49\end{array}$ & $\begin{array}{l}75 \\
68 \\
72 \\
74 \\
69 \\
77 \\
84 \\
79 \\
66 \\
64 \\
60 \\
65\end{array}$ & $\begin{array}{l}= \\
= \\
= \\
= \\
= \\
=\end{array}$ & $\begin{array}{l}= \\
= \\
= \\
= \\
= \\
=\end{array}$ & $\begin{array}{l}= \\
= \\
= \\
= \\
= \\
=\end{array}$ & $\begin{array}{l}= \\
= \\
= \\
= \\
= \\
=\end{array}$ \\
\hline
\end{tabular}

T A B L E I I I ANDERSEN SAMPLER COUNTS (TOTAL COLONIES ON 6 PETRI DISHES)

$40^{\circ}$ C Fungi

Aspergillus nidulans

Trichoderma Koningi

Humicola stellata

Absidia

Penicillium piceum

Yeast

? Paecilomyces

$25^{\circ}$ C Fungi

Penicillium

Aspergillus fumigatus

Aspergillus versicolor

Scopulariopsis

Paecilomyces

Trichoderma

Absidia

Mucor spinosus

Yeast

Chaetomium

Oidiodendron

$60^{\circ} \mathrm{C}$ Actinomycetes and bacteria

Thermoactinomyces vulgaris

Others

Bacteria

$40^{\circ} \mathrm{C}$ Actinomycetes and bacteria

Thermoactinomyces vulgaris

White thermomonospora

? Nocardia

Bacillus licheniformes

Other bacteria

$25^{\circ} \mathrm{C}$ Actinomycetes and bacteria

Grey-green colonies

Ash-grey colonies

Bacteria
Aspergillus fumigatus

Thermoactinomyces viridis

T A B L E I V

SPECIES OF PENICILLIUM ISOLATED FROM MOULDY CORK

\begin{tabular}{|c|c|c|}
\hline $\mathbf{A}$ & $\mathbf{B}$ & C \\
\hline 1 & - & - \\
\hline 3 & - & - \\
\hline 1 & 1 & - \\
\hline 2 & - & - \\
\hline 1 & - & - \\
\hline i & - & - \\
\hline 1 & 3 & $\rightarrow$ \\
\hline- & 1 & - \\
\hline 90 & 151 & 103 \\
\hline 1 & - & 1 \\
\hline 50 & - & - \\
\hline 2 & - & 一 \\
\hline 1 & - & 一 \\
\hline 1 & 1 & - \\
\hline $\begin{array}{l}3 \\
6\end{array}$ & 二 & $\overrightarrow{1}$ \\
\hline 5 & - & 3 \\
\hline 1 & $\overrightarrow{10}$ & $\overrightarrow{63}$ \\
\hline & & \\
\hline 6 & 13 & 3 \\
\hline- & 4 & $\overline{1}$ \\
\hline - & 2 & 1 \\
\hline 7 & 2 & 一 \\
\hline 4 & 二 & - \\
\hline 1 & $\longrightarrow$ & 1 \\
\hline 1 & 1 & 1 \\
\hline-3 & $\begin{array}{l}2 \\
3\end{array}$ & $\begin{array}{l}1 \\
1\end{array}$ \\
\hline 1 & 一 & - \\
\hline $\overrightarrow{0}$ & $\overline{7}$ & 1 \\
\hline 9 & 7 & 9 \\
\hline
\end{tabular}

$A=$ cork dust ; $B=$ cork dust 'with traces of mould'; $C=$ cork 'with obvious white mould'. 
T A B LE VI

DUAL SKIN TEST REACTIONS TO MOULDY CORK AND Penicillium frequentans

\begin{tabular}{|c|c|c|c|c|}
\hline \multirow[b]{3}{*}{ Reaction } & \multicolumn{4}{|c|}{ No. of Positives/No. of Cases Studied } \\
\hline & \multirow{2}{*}{\multicolumn{2}{|c|}{$\begin{array}{rc}\text { Mouldy } & \text { Cork } \\
\text { Immediate } & \text { Late }\end{array}$}} & \multicolumn{2}{|c|}{ Penicillium frequentan } \\
\hline & & & Immediate & Late \\
\hline Cork workers with & $1 / 4$ & $0 / 4$ & $2 / 4$ & $0 / 4$ \\
\hline $\begin{array}{l}\text { Cork workers with } \\
\text { extrinsic allergic } \\
\text { alveolitis }\end{array}$ & $14 / 16$ & $16 / 16$ & $11 / 12$ & $12 / 12$ \\
\hline
\end{tabular}

T A B LE V I I

INHALATION TEST REACTIONS

\begin{tabular}{|c|c|c|c|c|c|c|}
\hline \multirow[b]{2}{*}{ Patient } & \multicolumn{3}{|c|}{ Mouldy Cork } & \multicolumn{3}{|c|}{ Penicillium frequentans } \\
\hline & $\begin{array}{l}\text { Bronchial } \\
\text { Immediate } \\
\text { Reaction }\end{array}$ & $\begin{array}{l}\text { Bronchial } \\
\text { Late } \\
\text { Reaction }\end{array}$ & $\begin{array}{l}\text { Alveolar } \\
\text { Reaction }\end{array}$ & $\begin{array}{l}\text { Bronchial B } \\
\text { Immediate } \\
\text { Reaction }\end{array}$ & $\begin{array}{l}\text { Bronchial } \\
\text { Late } \\
\text { Reaction }\end{array}$ & $\begin{array}{l}\text { Alveolar } \\
\text { Reaction }\end{array}$ \\
\hline $\begin{array}{l}\text { PC } 2 \\
\text { PC } 7 \\
\text { PC13 } \\
\text { PC20 } \\
\text { PC222 } \\
\text { PC25 } \\
\text { PC26 } \\
\text { PC27 } \\
\text { PC32 } \\
\text { PC34 } \\
\text { PC35 } \\
\text { PC47 }\end{array}$ & $\begin{array}{l} \pm \\
\pm \\
\pm \\
+ \\
+ \\
+ \\
\pm \\
\text { NT } \\
\text { NT } \\
\text { NT } \\
\text { NT }\end{array}$ & $\begin{array}{c}+ \\
+ \\
+ \\
+ \\
+ \\
+ \\
+ \\
+ \\
\text { NT } \\
\text { NT } \\
\text { NT } \\
\text { NT }\end{array}$ & $\begin{array}{l}+ \\
+ \\
+ \\
+ \\
+ \\
+ \\
+ \\
+ \\
\text { NT } \\
\text { NT } \\
\text { NT } \\
\text { NT }\end{array}$ & $\begin{array}{l}\text { NT } \\
+ \\
\text { NT } \\
\text { NT } \\
\text { NT } \\
\text { NT } \\
\text { NT } \\
\text { NT } \\
+ \\
\pm \\
+\end{array}$ & $\begin{array}{l}\text { NT } \\
+ \\
\text { NT } \\
\text { NT } \\
\text { NT } \\
\text { NT } \\
\text { NT } \\
\text { NT } \\
+ \\
+ \\
+\end{array}$ & $\begin{array}{l}\text { NT } \\
+ \\
\text { NT } \\
\text { NT } \\
\text { NT } \\
\text { NT } \\
\text { NT } \\
\text { NT } \\
+ \\
+ \\
+\end{array}$ \\
\hline
\end{tabular}

-negative reaction; + positive reaction; NT $=$ not tested

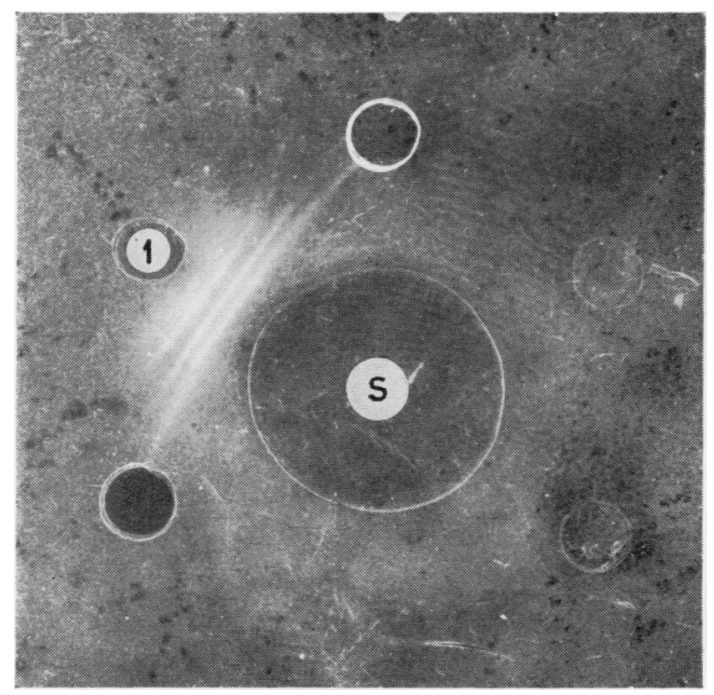

FIG. 1. Agar double-diffusion plate: $S=$ patient's serum 'PC 13'; $1=$ antigen of Penicillium frequentans in $a$ dilution of $50 \mathrm{mg} / \mathrm{ml}$ saline solution. formation of reticulin fibres and collagen fibres. The biopsy specimen of lung from a patient taken shortly after an acute crisis showed a different appearance (Fig. 3). The septa were markedly widened and the alveoli were reduced to slits filled with oedema fluid and granular pneumocytes. Once again, the infiltration of the widened septa was composed of oedema fluid, numerous lymphocytes, some histiocytes, and very few fibroblasts. Considerable deposits of cork dust were noted both in the granular pneumocytes and in the septal histiocytes. In patients with the insidious form of the disease, thickening of the septa was once again due to the formation of reticulin fibres and infiltration of histiocytes containing cork dust (Fig. 4). In 12 cases there were sarcoid-like granulomata of epithelioid cells similar to those found in acute crisis. These were numerous and dominated the histological picture.

A patient in this acute stage of the disease was studied who had had manifestations of an insidious extrinsic allergic alveolitis for approximately four months. This patient became intensely ill and died in acute respiratory failure within a few days. In this case the lungs showed interstitial lesions similar to those reported above plus 'honeycombing' with large numbers of sarcoid-like follicles and epithelioid cells which resembled a very severe form of miliary tuberculosis (Fig. 5). However, bacteriological examination was undertaken to show tubercle bacilli and proved to be negative both on the patient's sputum and on the lung tissue at necropsy. On the other hand the granulomata contained fine inclusions of cork dust (Fig. 6).

The manifestations of the chronic stage of the disease were preceded, in five patients, by one or more acute crises. In seven other patients the development of symptoms was insidious and of variable duration. In the remaining four patients the extrinsic allergic alveolitis was present from the onset as the chronic stage of the disease. The time lapse between the first symptoms and the recognition of the chronic stage varied from five months to 39 years. The most frequently reported symptoms were persistent breathlessness on exercise (8 patients), breathlessness on exercise plus a persistent cough (4 patients), and progressively increasing breathlessness ( 4 patients).

Chest radiographs showed fibrotic lesions, associated in six films with a fine nodulation.

Ventilatory function tests showed a restrictive defect in 12 patients, associated with an obstructive defect in four (Table II). Electrocardiographic signs of cor pulmonale (Friedberg, 1966) were found in eight patients. The time lapse between the 


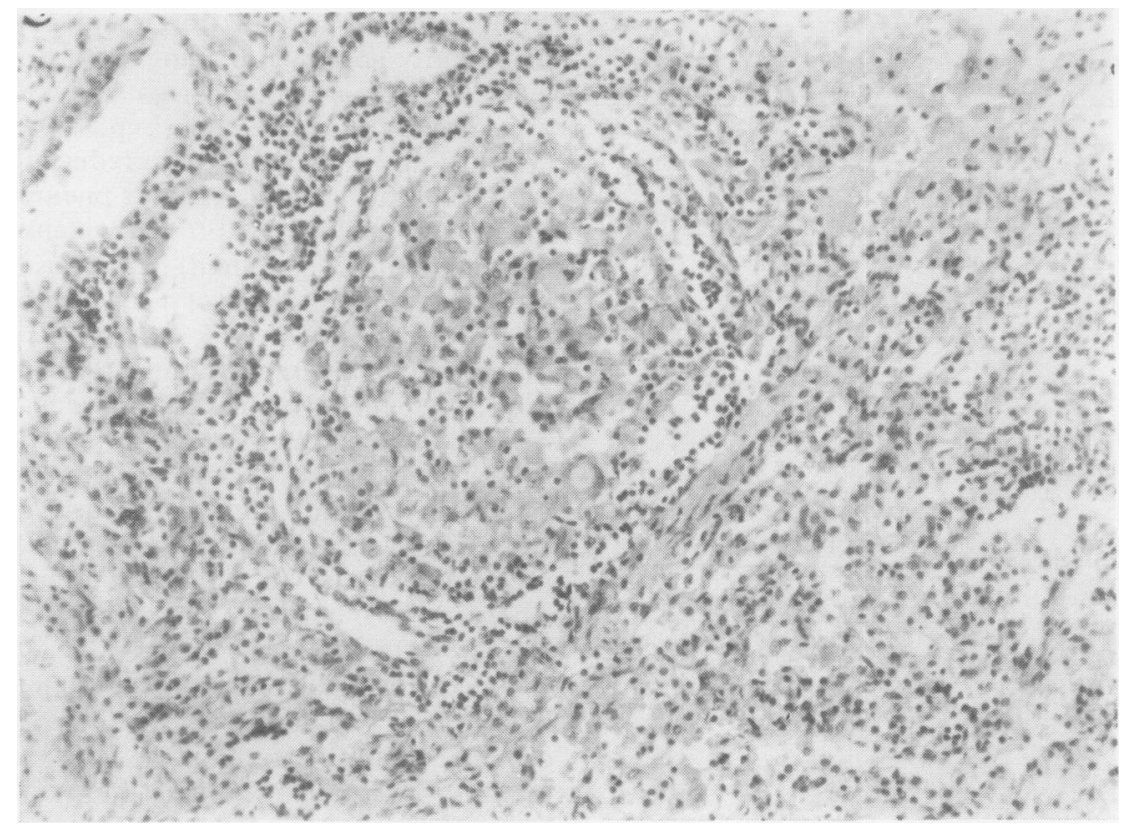

FIG. 2. Extrinsic allergic alveolitis, acute stage, insidious onset. Epithelioid granuloma with a Langhans type giant cell and a peripheral lymphocytic border. (H and $E \times 45)$

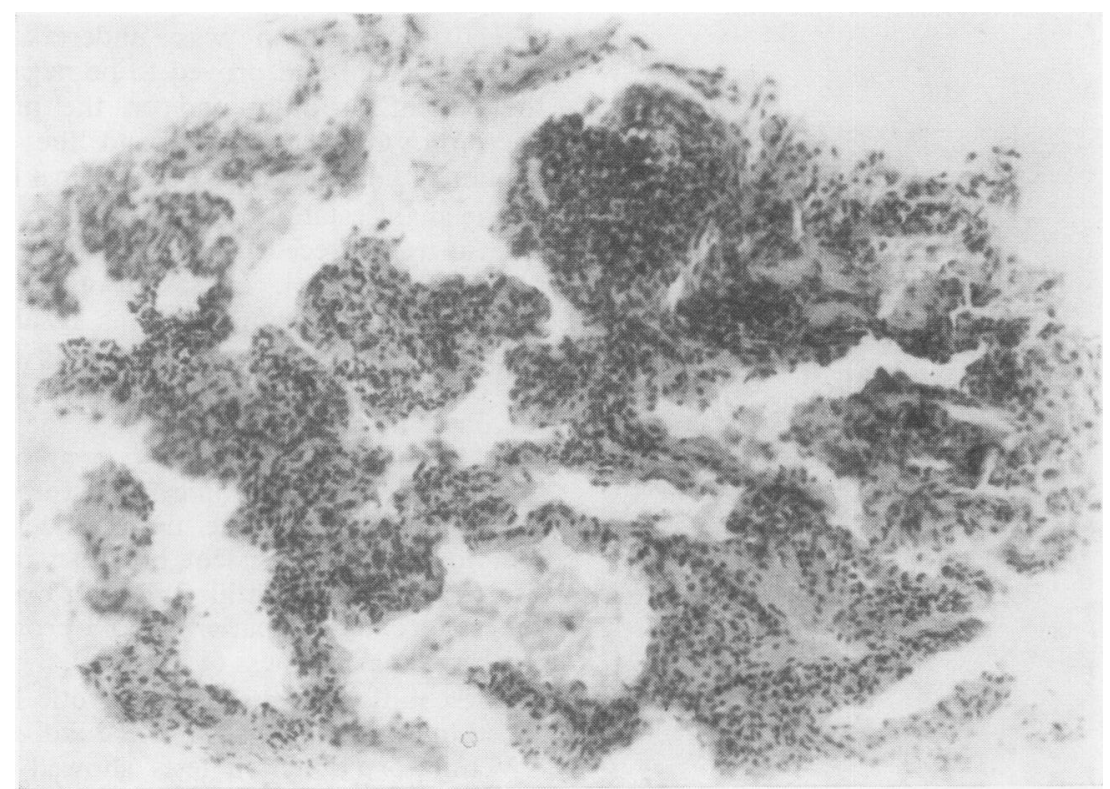

FIG. 3. Extrinsic allergic alveolitis, acute stage. Transbronchial lung biopsy taken during a crisis. Greatly thickened interalveolar septa due to oedema and predominantly lymphocytic cellular infiltration. ( $H$ and $E \times 35$ ) 


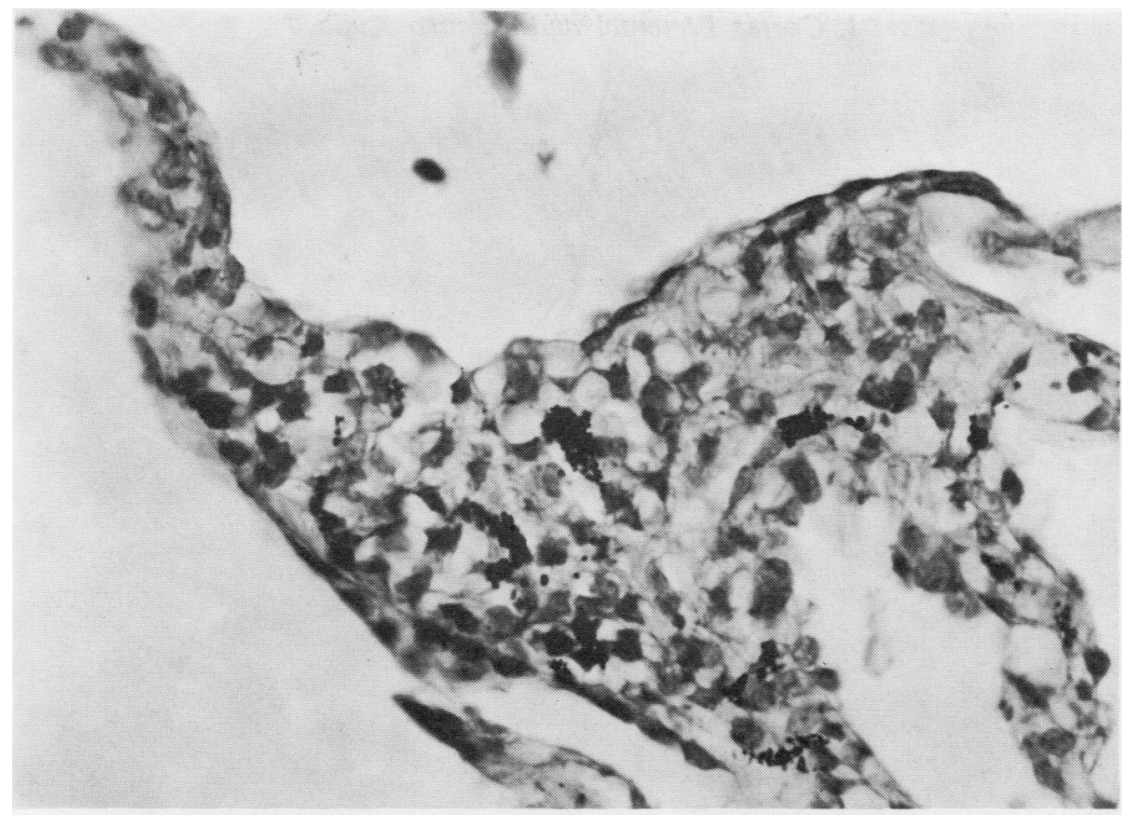

FIG. 4. Extrinsic allergic alveolitis, acute stage, insidious onset. Detail of an interalveolar septum. Cellular infiltration of histiocytes, many with inclusions of cork dust. ( $H$ and $E \times 20)$

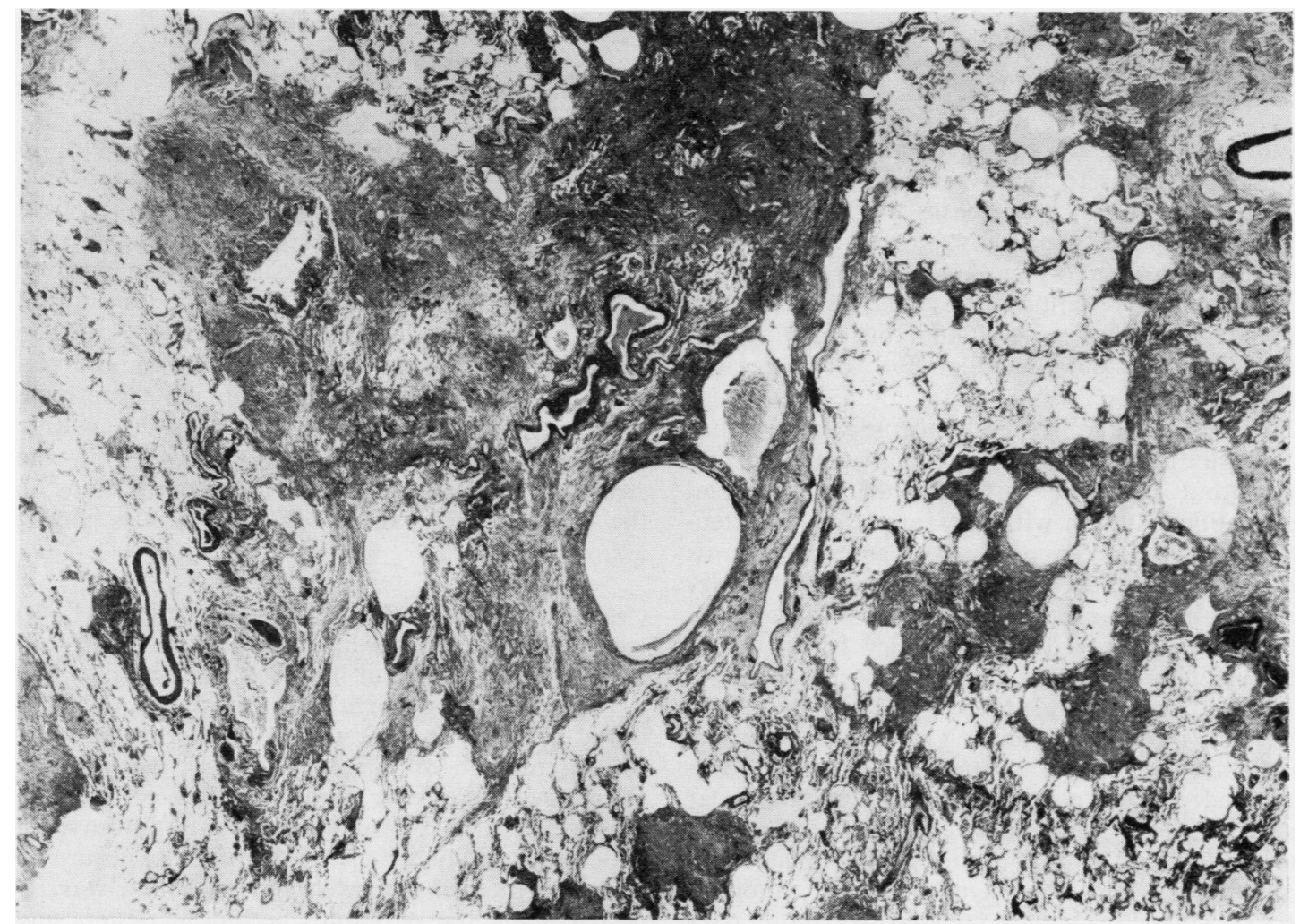

FIG. 5. Extrinsic allergic alveolitis, acute stage, insidious onset and fatal acute exacerbation. Numerous sarcoid-type epithelioid granulomata, often conglomerated. Aspects of emphysema and honeycombing. $(H$ and $E \times 20)$ 


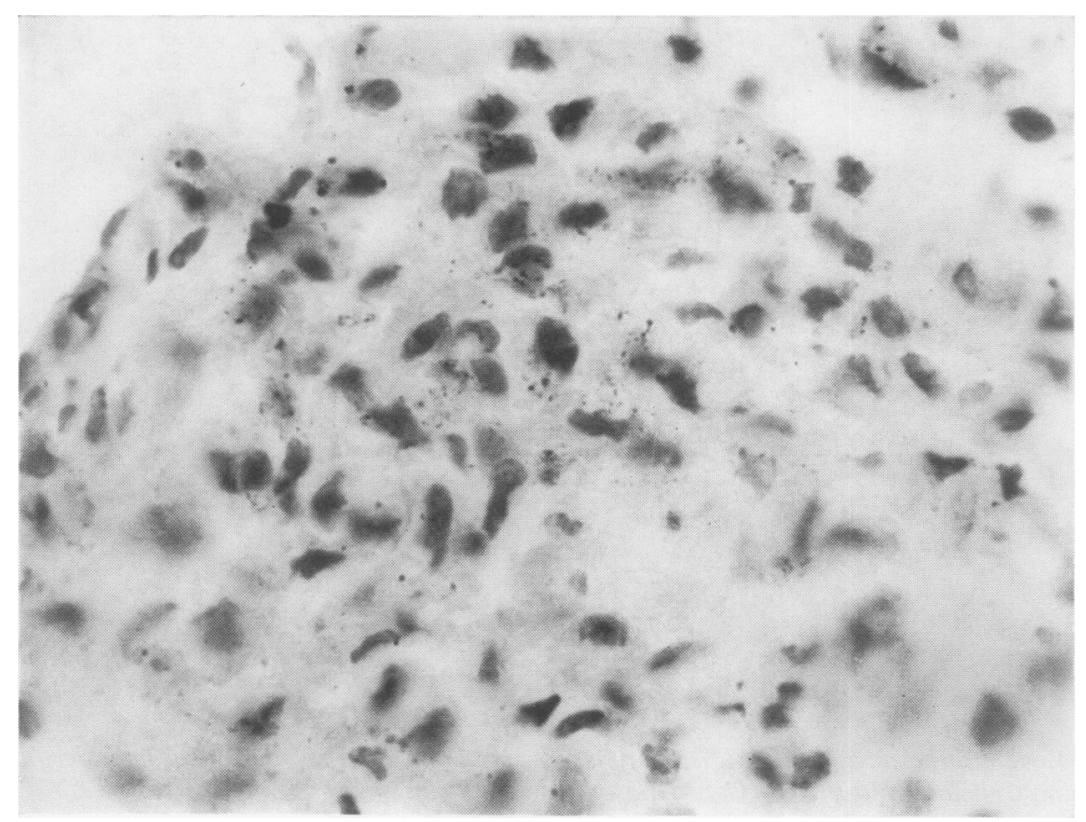

FIG. 6. Detail of a sarcoid-type epithelioid granuloma stained by the cochineal red technique. Fine black (red in the slides) nodulation corresponding to inclusions of cork dust. ( $H$ and $E \times 490)$

beginning of the chronic stage and death varied from five months to seven years.

At necropsy in all these cases the lungs showed diffuse fibrosis. The severity of this varied from case to case and in any one case from lobe to lobe. Also present were emphysema and honeycombing. The large bronchi were dilated but in all cases there was considerable dilatation of the right ventricle.

Histological examination confirmed the presence of diffuse fibrosis. Sometimes the alveoli were preserved but in other instances there was total obliteration of them with the formation of extensive sheets of scar tissue (Fig. 7). There was fibrosis around the bronchi and the smaller pulmonary blood vessels. Thickening of the alveolar septa was prominent and was due to the new formation of reticulin with dense cellular infiltrates of lymphocytes, histiocytes, and plasma cells with a few neutrophils and eosinophils. The alveoli were frequently reduced to slits and the epithelium was often oedematous, giving rise to a pseudoglandular appearance. In many areas groups of granular pneumocytes or multinucleated alveolar cells had desquamated into the alveoli. The pulmonary arteries showed changes related to pulmonary hypertension. In six cases there were granulomata of sarcoid type consisting of epithelioid cells. In three instances small, nodular fibrotic foci appeared to be the scars of such granulomata. In eight instances, foreign body type granulomata were present and in three there was extensive deposition of calcium cells. The hilar lymph nodes showed areas of scarring and of sinus histiocytosis. In these instances there were sarcoid-type granulomata in the hilar lymph nodes. In all these cases there were abundant deposits of cork dust within the desquamated granular pneumocytes, in the swollen epithelial cells, in the septal infiltrations, in the sarcoid type granulomata, and in the fibrotic areas.

CHRONIC BRONCHITIS WITH BRONCHIECTASIS Fourteen of the 16 patients in this group gave a history of prolonged bronchial irritation. At first they had a persistent, very slightly productive cough followed later by breathlessness on exertion, production of mucoid or purulent sputum, pains in the chest, low-grade fever, weakness, lack of appetite, and weight loss. At first all these symptoms disappeared rapidly when the patient's exposure to cork dust ceased, only to return when it was renewed. Later the symptoms became persistent and were often aggravated when the patient was ex- 


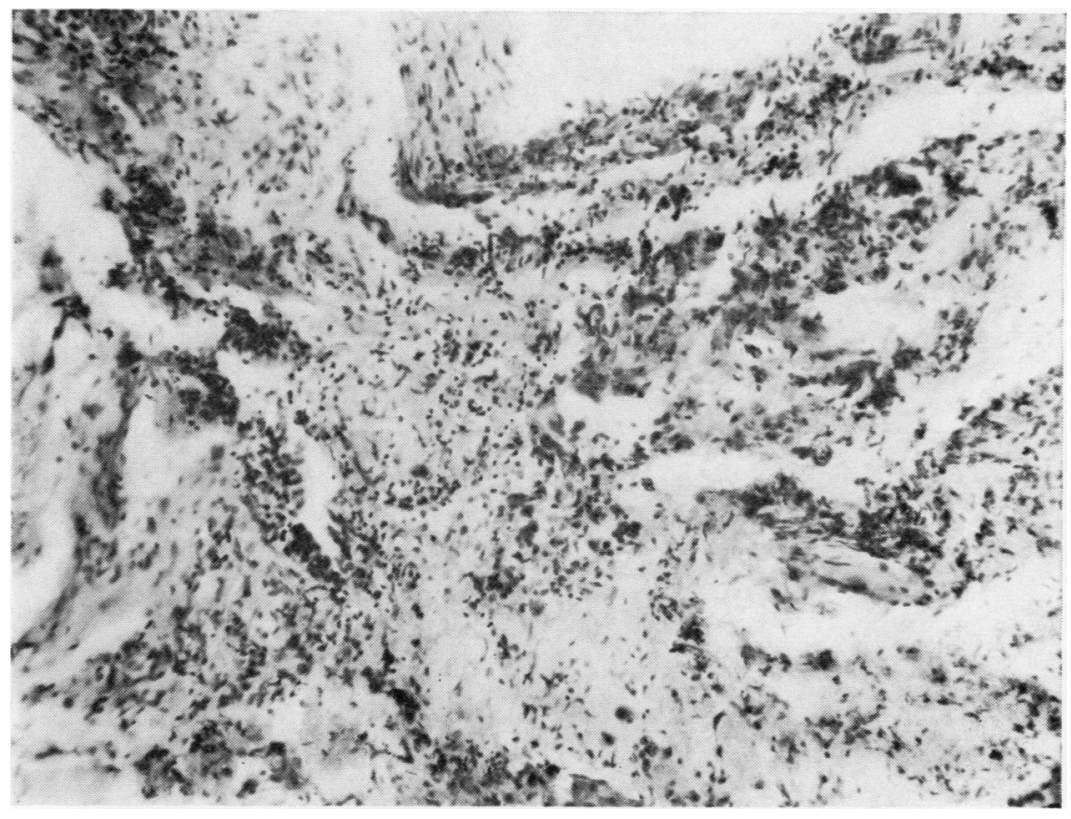

FIG. 7. Extrinsic allergic alveolitis, chronic stage. Extensive changes in the alveolar structure due to fibrous tissue with infiltrations and numerous depositions of cork dust. $(H$ and $E \times 38)$

posed to high concentrations of cork particles.

After several years of working in the factory environment ( 6 to 20 years in the patients reviewed) the disability became worse, and the sputum was purulent, abundant, and at times blood-streaked. Even small haemoptyses occurred. These patients had disseminated wheezes and the chest radiographs showed enlarged hilar shadows and increased lung markings. Bronchography revealed cylindrical or saccular bronchiectasis in all patients, generally limited to the lower lobes. Ventilatory function tests showed restrictive defects in 10 patients with an associated obstructive defect in five.

All these patients had pulmonary resections for their bronchiectasis, after which they improved slightly, especially in relation to suppuration and blood streaking. However, later there was slowly progressive respiratory failure.

Examination of the surgical specimens of lungs of these patients confirmed the presence of bronchiectasis. There were within the walls of the bronchi, in the peribronchial and vascular connective tissues, and in the neighbouring alveolar septa pronounced inflammatory exudates of histiocytes, lymphocytes, plasma cells, and eosinophils. Sometimes there was fibrosis and the formation of reticulin fibres. Large amounts of cork dust were deposited in these lesions, especially in the peribronchial vascular connective tissue, in the alveolar septa, and in the cytoplasm of granular pneumocytes found in the alveolar spaces.

A slightly different clinicopathological picture was seen in two patients of this group. Their history was shorter, only a few months, and their main symptoms were persistent cough and bloodstreaked sputum. Chest radiographs showed segmental shadows that led to the clinical diagnosis of lung cancer. This diagnosis was not confirmed by bronchoscopy nor by sputum cytology. Exploratory thoracotomy showed lesions identical with those described above together with 'endogenous lipoid pneumonia' responsible for the tumour-like aspects seen on radiographs.

The results of immunological studies of these patients with chronic bronchitis and bronchiectasis were similar to those found in cork workers with extrinsic allergic alveolitis.

PATHOLOGICAL STUDIES OF ASYMPTOMATIC CORK WORKERS All the asymptomatic cork workers whose lungs became available for pathological examination had lesions although these could be seen only with a magnifying glass or on microscopy.

In one man who had worked with cork for 


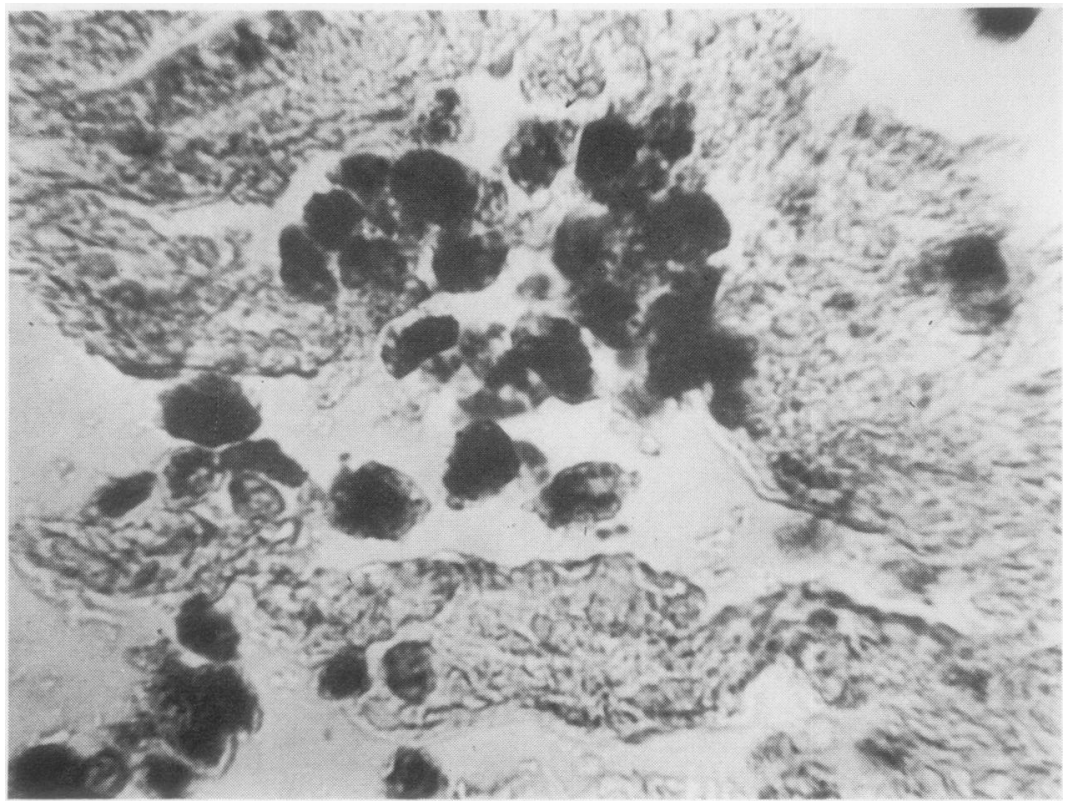

FIG. 8. Prescalene node biopsy from a patient with chronic bronchitis and bronchiectasis type of suberosis. 'Sinus histiocytosis'. The dark colour of the histiocytes is due to inclusions of cork dust. Cochineal red technique. ( $H$ and $E \times 590)$

only four months discrete lesions were found. These consisted of a chronic inflammatory reaction in the main bronchi and in the connective tissues around bronchi and pulmonary blood vessels and also in the nearby alveoli. Once again the cellular infiltrate was composed of lymphocytes, histiocytes, and eosinophils. Small deposits of cork dust were seen in granular pneumocytes in the alveolar spaces and in some of the histiocytes in the cellular infiltrates. In the other five patients who had received contact with cork dust for from 6 to 18 years the lesions were more pronounced. They involved bronchi of various sizes, the connective tissue of the bronchi and pulmonary blood vessels, and more distant alveolar septa, some of which had no continuity with peribronchial connective tissue. The bronchial and peribronchial infiltrates were similar to those found in the first case but there was a more or less marked fibrotic element. In one of the cases who had been exposed for six years sarcoid-like granulomata were seen. Some of these appeared to be recent but others were old and scarred.

The lungs of all workers with more than six years of exposure to cork dust showed considerable deposits of such dust in desquamated granular pneumocytes, in multinucleated alveolar cells, in histiocytes, in the walls of the bronchi, in the connective tissue around bronchi and pulmonary을 blood vessels, and in the tracheobronchial lymph nodes.

PATHOLOGICAL EXAMINATION IN PATIENTS WITHo EXTRINSIC ALLERGIC ALVEOLITIS IN THE CHRONIC $\underset{\times}{\grave{2}}$ STAGE, REMOVED FROM EXPOSURE TO CORK DUST $\bar{\sigma}$ FOR LONG PERIODS The lungs of two patients in 3 . these conditions were examined. One patient had $\bigcirc$ worked with cork for 35 years and had suffered from repeated acute attacks of extrinsic allergico alveolitis with asthma-like crises after being exposed for 20 years. Six years later the processo became chronic and was diagnosed as " pulmonary fibrosis', confirmed by lung biopsy.

In this biopsy of lung there was a chronic stage N of alveolitis with extensive fibrosis, and pronounced N infiltration of lymphocytes and histiocytes, granulomata of sarcoid-like appearance, and abundant deposits of cork dust. This patient improved con- $-\frac{\tau}{\Phi}$ siderably on retirement and died six years later in an accident. At necropsy his lungs showed diffuse 0 interstitial fibrosis which was largely collagenous. In this instance there were no sarcoid-like granulomata and the cellular infiltrate seen in the biopsy specimen six years before had gone. In this case there was much less cork dust than in the original biopsy specimen. 
T A B L E V I I I

LESIONS SEEN IN SCALENE NODE BIOPSIES OF 16 PATIENTS WITH SUBEROSIS STUDIED BY THE COCHINEAL RED TECHNIQUE

\begin{tabular}{|c|c|c|c|c|c|}
\hline \multirow{2}{*}{$\begin{array}{c}\text { Clinicopathological Forms of } \\
\text { Suberosis }\end{array}$} & \multirow{2}{*}{$\begin{array}{l}\text { No. of } \\
\text { Patients }\end{array}$} & \multicolumn{2}{|c|}{ Sinus Histiocytosis } & \multirow{2}{*}{$\begin{array}{l}\text { Sarcoid Granulomata } \\
\text { with Cork Dust }\end{array}$} & \multirow{2}{*}{ Fibrosis } \\
\hline & & $\begin{array}{l}\text { With Cork } \\
\text { Dust }\end{array}$ & $\begin{array}{l}\text { Without } \\
\text { Cork Dust }\end{array}$ & & \\
\hline $\begin{array}{l}\text { Extrinsic allergic alveolitis (acute and } \\
\text { chronic stage) }\end{array}$ & 7 & 3 & - & 4 & 一 \\
\hline $\begin{array}{l}\text { Chronic bronchitis and bronchiectasis } \\
\text { Chronic bronchitis and bronchiectasis } \\
\text { and segmental tumour-like } \\
\text { condensations }\end{array}$ & $\begin{array}{l}8 \\
1\end{array}$ & $\begin{array}{l}2 \\
1\end{array}$ & -1 & $\underline{2}$ & 1 \\
\hline
\end{tabular}

The other patient had worked with cork for 38 years and his clinical manifestations were those of chronic respiratory insufficiency. Surgical biopsy showed the chronic form of extrinsic allergic alveolitis very like that of the first patient, only more severe and with areas of honeycombing and emphysema. He did not improve with retirement and died two years later of myocardial infarction. Pathological examination of the lungs confirmed the biopsy findings. There were also dense inflammatory cellular infiltrates in the bronchial walls, in the peribronchovascular connective tissue, and in the interalveolar septa. All these lesions contained plentiful deposits of cork dust.

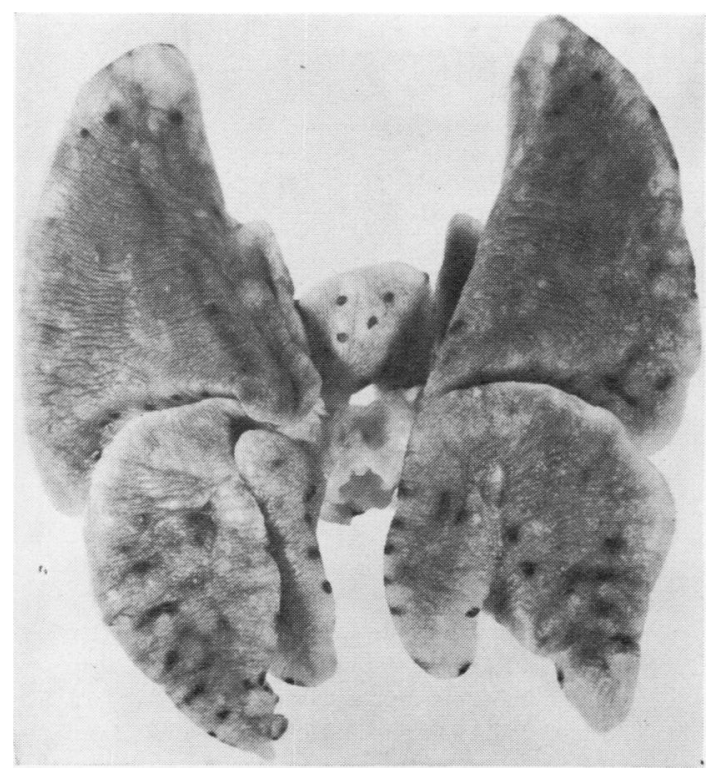

FIG. 9. Lung of a guinea-pig sacrificed after 1,168 days of exposure to cork dust. The black subpleural nodules correspond to sarcoid-type granulomata. (Reproduced by courtesy of the Jornal da Sociedade das Ciéncias Médicas de Lisboa.)
EXTRAPULMONARY LESIONS Lesions related to the presence of cork dust were found in the nasal mucosa, in the lymph glands (hilar, paratracheal, and carinal), and in the liver.

The changes in the nasal mucosa, studied in five patients, were consistent with those found in allergic rhinitis. In two patients there were small granulomata made up of histiocytes with inclusions of cork dust.

The lymph glands from 15 patients were studied: in five sinus histiocytosis was seen and in two sarcoid-type granulomata. Cork dust was identified in the histiocytes desquamated into the lymph node sinuses and in the granulomata.

A small sarcoid-type granuloma with inclusions of cork dust was found in one of the sections of liver.

PRESCALENE NODE BIOPSY Prescalene nodes from 16 patients with suberosis were studied histologically using the cochineal red technique to stain the cork dust. Table VIII summarizes the results obtained in the various forms of the disease. Cork dust was identified in histiocytes of a ' sinus histiocytosis 'in six patients (Fig. 8) and also in six nodes showing granulomata.

EXPERIMENTAL STUDIES The lesions in the lungs of 23 guinea-pigs and 7 rabbits that had been exposed to cork dust in various departments of a cork factory were studied. Guinea-pigs exposed for shorter periods-less than 126 days - showed only discrete accumulations of cork dust within some granular pneumonocytes in the alveoli, with no particular topographical distribution. In eight animals, whose exposure exceeded 194 days, the number of these cells increased appreciably and they accumulated particularly in the subpleural alveoli. In animals sacrificed after an exposure of more than 194 days the presence of cork-laden histiocytes in the alveolar septa was first noted. These deposits became progressively larger in animals with longer exposures, and a thickening 


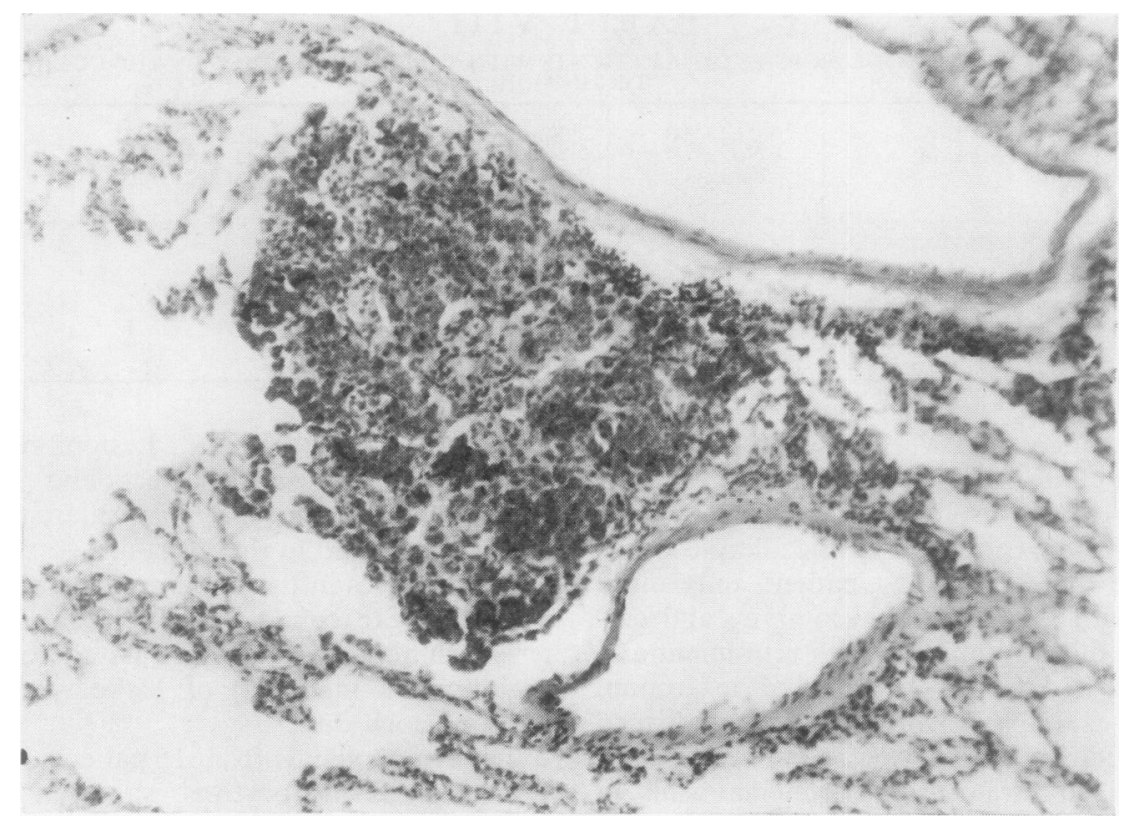

FIG. 10. Lung of a rabbit sacrificed after 1,100 days of exposure to cork dust. Sarcoidtype epithelioid granulomata. Between the granulomata some alveoli are filled with plugs of granular pneumocytes. ( $H$ and $E \times 75$ )

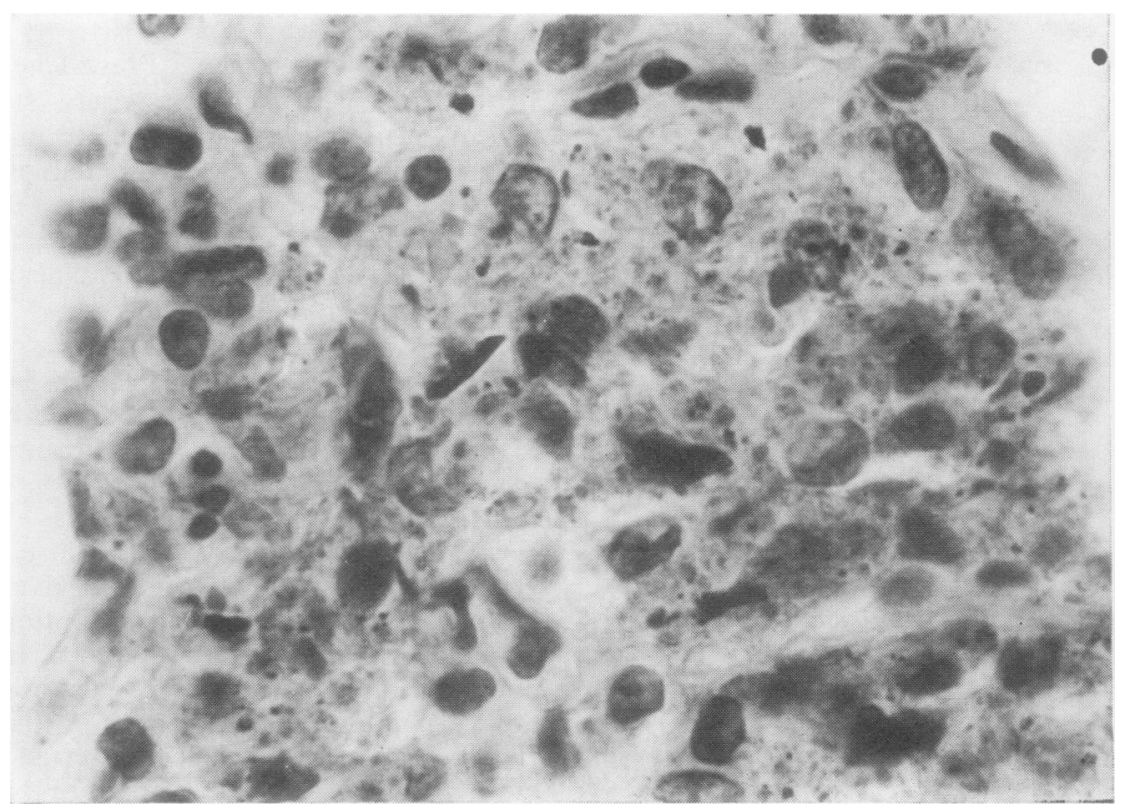

FIG. 11. Details of a granuloma from Fig. 10. Abundant inclusions of cork particles of various forms and sizes. ( $H$ and $E \times 480$ ) 
of the septa, partly due to infiltration with histiocytes, fibroblasts, and some lymphocytes, and partly to neoformation of reticulin fibres, became apparent. In two animals exposed for 211 and 336 days, intra-alveolar giant cells were seen for the first time. This was a frequent finding in animals with longer exposures. In seven animals exposed for more than 438 days there was a marked tendency for granular pneumonocytes laden with cork dust to accumulate in the lumen of neighbouring alveoli, giving a nodular appearance very similar in appearance and distribution to "haemosiderotic nodules'. This was visible to the naked eye and was more marked in the subpleural area although it was also present in other parts of the lung. Finally, in four animals exposed for 512, $1,168,1,180$, and 1,278 days respectively, some sarcoid-type granulomata with intracellular inclusions of cork dust were seen. These were also more plentiful in the subpleural region (Fig. 9), near the interlobar septa, and in the peribronchovascular connective tissue. These granulomata were always found near alveoli filled with plugs of granular pneumonocytes.

The seven rabbits exposed to cork dust in similar conditions showed lesions in the lungs practically identical with those described in the guineapigs. These consisted of septal thickening from lymphohistiofibroblastic infiltration and neoformation of reticulin fibres in animals exposed for less than 276 days. Those exposed for longer (729, 839, and 1,100 days) had sarcoid-type granulomata, also near alveoli filled with granular pneumonocytes (Fig. 10). Cork dust was identified in the same sites as in the guinea-pigs (Fig. 11).

\section{DISCUSSION}

The findings of this study lead us to believe that workers in the cork industry may suffer from various complaints directly related to the inhalation of cork dust. These may present clinically as asthma-like syndromes, as an interstitial disease similar to extrinsic allergic alveolitis (farmer's lung, Pepys et al., 1964 ; bird fancier's lung, Nash, Vogelpoel, and Becker, 1967 ; furrier's lung, Pimentel, 1970) and as chronic bronchitis and bronchiectasis. All these conditions may be included under the general heading of suberosis, a term introduced by Cancella (1955) to describe a localized interstitial disease of the lung in cork workers.

The asthma-like syndrome reflects an immediate bronchial reaction to the inhalation of cork dust. The most representative morphological feature of this syndrome is a cellular infiltration of the bronchial walls which contains many eosinophils and intracellular inclusions of cork dust.

The initial manifestations of extrinsic allergic alveolitis appear in two distinct forms - an acute type, in which the patients have symptoms only when in their working environment, and an insidious type, in which the symptoms are always present but exacerbation occurs with further exposure to cork dust. These exacerbations are attenuated with further exposure and after a time they become unrecognizable. This may be explained by the constant antigenic stimulus due to a permanent exposure to cork dust, as many of the workers live near the factories and have cork dust in their living environment. This stimulus may be sufficient to keep up a constant response. The results of the inhalational provocation tests seem to support this idea as the response depends on the concentration of antigen used in the tests. When the concentration of the antigen is increased functional changes and clinical manifestations are produced in patients who responded to lower concentrations with functional changes only.

Respiratory function tests, at rest and outside the factory environment, showed various types of ventilatory abnormalities in which restriction dominated, although an obstructive element was sometimes present. All patients had a late bronchial response to respiratory challenge with cork dust, similar to that found by Pepys, Hargreave, Longbottom, and Faux (1969) in farmer's and bird fancier's lung.

The pathological changes in the lungs of this group of cork workers were characterized by oedema and cellular infiltration of the interalveolar septa, neoformation of reticulin and collagen fibres, and sarcoid-type epithelioid granulomata, as found in other forms of extrinsic allergic alveolitis. Cork dust was systematically and constantly found in the granular pneumonocytes in the alveoli, in the histiocytes of the septal infiltrates, and in the granulomata. The latter can be the predominant pathological feature of the disease, as seen in two cases of the insidious type, one of which had a terminal exacerbation that led to death in respiratory failure. This case is very similar to the case of farmer's lung that ran a rapidly fatal course described by Barrowcliff and Arblaster (1968).

The patients with chronic bronchitis have symptoms of bronchial irritation. These are initially slight and brought on only by exposure to high concentrations of cork dust, but later they become more severe and permanent. The bronchial mucosa of these patients shows a chronic inflammatory 
process, generally with as many eosinophils as in the asthma-like syndromes.

Both the bronchitis and extrinsic allergic alveolitis varieties of suberosis may progress to the severe chronic stage. Thus, patients with signs of early bronchial irritation later show signs of bronchial suppuration and haemorrhage clinically related to the presence of bronchiectasis, apparently localized to one lobe. Although resection of this diseased area produces some symptomatic improvement there is a slow progression towards respiratory failure due to the disseminated nature of the disease. The pathological changes in the lungs of these patients are of an inflammatory and fibrosing nature and involve predominantly the bronchi and the peribronchovascular, interlobar, and subpleural connective tissue. Inclusions of cork dust are found within these lesions.

The patients with extrinsic allergic alveolitis due to cork dust may also progress towards a chronic form characterized clinically by progressive respiratory insufficiency and pathologically by a diffuse interstitial fibrosis, often associated with honeycombing.

The various forms of lung disease found in cork workers do not constitute distinct entities. Thus, in patients with asthma-like syndromes and chronic bronchitis and bronchiectasis, involvement of the interstitium of the lung, and even sarcoid-like granulomata, are frequently found. On the other hand, in patients in whom signs of extrinsic allergic alveolitis predominate, bronchial lesions, frequently with abundant eosinophilic infiltrations, may be found. Our clinical studies have also shown that continued exposure to cork dust can bring on asthma-like syndromes in patients whose original complaints were of the allergic alveolitis type. This duality of response has been reported in extrinsic allergic alveolitis due to the inhalation of other organic dusts (Carrego, 1968) and was described by Pepys et al. (1968) in subjects sensitized to the enzymes of Bacillus subtilis.

Our investigations have also attempted to throw some light on two very important aspects of suberosis - the course of the chronic lesions in patients removed from exposure to cork dust for long periods of time and the condition of the lung in asymptomatic cork workers.

The scarcity of appropriate material did not permit us to form a very significant opinion on the first problem. However, our observations seem to show that removal of the patient from heavy exposure may stop the progression of the disease and allow the healing of existing lesions to take place if the process is not too widespread or has not caused $\stackrel{\overrightarrow{\vec{S}}}{+}$ irreparable complications.

As to the second point, our findings suggest that $\frac{\overline{\bar{D}}}{\overline{\mathrm{s}}}$ the idea that only some people exposed to organic dusts develop extrinsic allergic alveolitis may not $\stackrel{\mathbb{Q}}{2}$ be wholly true. The lungs of all the asymptomatic cork workers examined had lesions similar to those $\vec{\circ}$ found in the symptomatic workers, even to the point of having epithelioid granulomata. However, $\vec{\omega}$ these lesions were more discrete and less numerous. These findings suggest, subject to further confirma- $-\vec{x}$ tion, the existence of subclinical forms of the $N_{\infty}$ disease that should not be neglected.

The diagnosis of suberosis can be made by immunological techniques or by the histological examination of lung tissue and, in some cases, of $\frac{}{3}$ the scalene lymph nodes.

Skin sensitivity and inhalational provocation tests were conclusive when mouldy cork antigens were used but this was not so as far as the immunochemical techniques were concerned. The fact that ${ }^{\omega}$ many patients were more troubled by the dust resulting from the manipulation of slabs of mouldy cork led to mycological studies in an attempt toō identify the various fungi that grow on cork bark and to experimental work to determine if antigens $\stackrel{\mathbb{D}}{\stackrel{\mathbb{Q}}{ }}$ from any of these fungi could be useful in the $\overrightarrow{\vec{A}}$ diagnosis of suberosis, as has happened with other diseases of this type-maple bark disease? (Emanuel, Lawton, and Wenzel, 1962 ; Wenzel, Emanuel, and Lawton, 1967) ; farmer's lung (Pepys, Jenkins, Festenstein, and Gregory, 1965 ;응 Pepys and Jenkins, 1965) ; bagassosis (Salvaggio, Buechner, Seabury, and Arquembourg, $1966 ;$ Salvaggio, Seabury, Buechner, and Jundur, 1967).

Our investigations established Penicillium as theo fungal species most frequently identified on cork and serial immunological studies with antigense from all species of fungi grown on cork gaves significant and quite specific results with? Penicillium frequentans.

The diagnostic value of the morphological as $\Omega$ pects of the disease seems undeniable as it is possible to demonstrate the presence of cork dust within the lesions by using the cochineal red tech-o nique. The use of this technique in the study of scalene node biopsies greatly validates this methoo in the diagnosis of suberosis, even in those cases inf? which standard histological techniques show onlyo sinus histiocytosis.

Review of the experimental material has showris that there is a marked similarity between the lesions produced in animals and those found ing suberosis in man.

As to the nature of suberosis, already reporte 
(Avila and Villar, 1968 ; Pimentel, 1969), it seems to be an occupational disease caused by the inhalation of cork dust. Two factors seem to participate in its pathogenesis: (1) Cork dust within the lesions ; and (2) the existence of precipitating antibodies against Penicillium frequentans in the serum of patients with suberosis and they suggest a possible immunological reaction. However, we do not believe the second factor plays an important pathogenic role since this fungus may be just an habitual accompaniment of the inhaled organic material.

\section{REFERENCES}

Avila, R. (1965). Contribuição para o diagnóstico imunológico do 'aspergiloma pulmonar'. Thesis, Lisbon.

- and Araújo, A. T. (1971). Some considerations on ten cases of respiratory disease in cork workers. Pneumologia (Lisboa), 2, 17.

_ and Villar, T. G. (1968). Suberosis. Respiratory disease in cork workers. Lancet, 1, 620.

Barrowcliff, D. F., and Arblaster, P. G. (1968). Farmer's lung: A study of an early acute fatal case. Thorax, 23, 490.

Cancella, L. (1955). On a special kind of pneumoconiosis: Suberosis. Medicina Contemporânea, 73, 235.

Carrego, M. C. (1968). Mesa redonda sobre pulmão imunológico. IV Estudos laboratoriais. Jornal da Sociedade das Ciéncias Médicas de Lisboa, 133, 478.

Emanuel, D. A., Lawton, B. R., and Wenzel, F. J. (1962). Maple-bark disease. Pneumonitis due to Coniosporium corticale. New England Journal of Medicine, 266, 333.

Friedberg, C. K. (1966) Diseases of the Heart 3rd ed. Saunders, Philadelphia.

Horta, J. S., and Cancella, L. (1956). Experimentelle Korkstaubkoniose. Experimentelle Suberose. Archiv für Gewerbepathologie und Gewerbehygiene, 15, 319.
Hearn, C. E. D., and Holford-Strevens, V. (1968). Immunological aspects of bagassosis. British Journal of Industrial Medicine, 25, 283.

Nash, E. S., Vogelpoel, L., and Becker, W. B. (1967). Pigeon breeder's lung-A case report. South African Medical Journal, 41, 191.

Pepys, J. and Jenkins, P. A. (1965). Precipitin (F.L.H.) test in farmer's lung. Thorax, 20, 21.

Festenstein, G. N., and Gregory, P. H. (1963). Farmer's lung. Thermophilic actinomycetes as a source of "Farmer's lung hay" antigen. Lancet, 2607.

- Hargreave, F. E., Longbottom, J. L., and Faux, J. (1969). Allergic reactions of the lungs to enzymes of Bacillus subtilis. Lancet, 1, 1181.

_ Longbottom, J. L., and Jenkins, P. A. (1964). Vegetable dust pneumoconoisis. Immunologic response to vegetable dusts and their flora. American Review of Respiratory Diseases, 89, 842.

Pimentel, J. C. (1969). Pulmão imunológico. Mesa redonda. II Anatomia patológica. Jornal da Sociedade das Ciéncias Médicas de Lisboa, 133, 459.

- (1970). Furrier's lung. Thorax, 25, 387.

(1971). Fibrose difusa idiopática-Revisão de 2 casos em que foi identificado um provável agente etiológico. Jornal da Sociedade das Ciéncias Médicas de Lisboa, 133, 445.

Salvaggio, J. E., Buechner, H. A., Seabury, J. H. and Arquembourg, P. (1966). Bagassosis: precipitins against extracts of crude bagasse in the serum of patients with bagassosis. Anals of Internal Medicine, 64, 748.

- Seabury, J. H., Buechner, H. A. and Jundur, V. G. (1967). Bagassosis: demonstration of precipitins against extracts of thermophilic actinomycetes in the sera of affected individuals. Journal of Allergy, 39, 106.

Scheidegger, J. J. (1955). Une micro-méthode de l'immunoelectrophorèse. International Archives of Allergy and Applied Immunology, 7, 103.

Wenzel, F. J., Emanuel, D. A., and Lawton, B. R. (1967). Pneumonitis due to Micromonospora vulgaris (farmer's lung). American Review of Respiratory Diseases, 95, 652 . 